\title{
SEASONAL SEMIDECIDUAL FOREST FRAGMENT SOIL SEED BANK AND IT'S RELATIONSHIP WITH CONSERVATION ${ }^{1}$
}

\author{
João Juares Soares² and Sabrina Ferreira Laurito ${ }^{3 *}$
}

\footnotetext{
${ }^{1}$ Received on 16.09.2013 accepted for publication on 31.05.2017.

${ }^{2}$ Universidade Federal de São Carlos, São Carlos, São Paulo, Brasil. E-mail: <juares@ufscar.br>.

${ }^{3}$ Universidade Federal de São Carlos, Doutorado em Recursos Naturais, São Carlos, São Paulo, Brasil. E-mail:<salaurito@hotmail.com>.

*Corresponding author.
}

\begin{abstract}
Soil seed banks are the first source of seeds for regeneration after a forest's disturbance. The present study aims to verify the regeneration potential of the soil seed bank of a Seasonal Semidecidual Forest remnant. The study was carried out at Canchim Farm, CPPSE - Embrapa (São Paulo State, Brazil). Soil samples were collected from the fragment in both the wet and dry seasons. An average of 307.8 seedlings $/ \mathrm{m}^{2}$ was found in the dry season and an average of 144 seedlings $/ \mathrm{m}^{2}$ was found in the dry station. Twenty six species of trees with viable seeds were found in the soil, mostly pioneer species; among them, Cecropia glaziovi Snethlage was the most abundant pioneer species. The soil seed bank can be considered of great potential for regeneration due to the presence of pioneers, secondary and later species.
\end{abstract}

Keywords: Natural regeneration; Ecological succession; Tropical forest.

\section{O BANCO DE SEMENTES DE FRAGMENTO DE FLORESTA ESTACIONAL SEMIDECÍDUA E SUA RELAÇÃO COM O ESTADO DE CONSERVAÇÃO}

RESUMO - Após qualquer distúrbio na floresta a principal fonte de sementes para recolonização da área são as sementes presentes no solo. O presente trabalho analisa a existência de potencial de regeneração a partir do banco de sementes do solo de um fragmento de Floresta Estacional Semidecidual. O estudo foi realizado na Fazenda Canchim, CPPSE - Embrapa, São Carlos, São Paulo. Foram coletadas 50 amostras da superficie do solo com cinco centímetros de profundidade no interior do fragmento no final das estações chuvosa e seca. Encontraram-se valores de densidade de 307,8 sementes germinadas $/ m^{2}$ na estação chuvosa e 144 sementes germinadas $/ m^{2}$ na estação seca. Ocorreram vinte e seis espécies arbóreas com sementes viáveis no solo, a maioria de pioneiras, entre estas, Cecropia glaziovi Snethlage foi a mais abundante. O banco de sementes do solo demonstrou potencial de regeneração devido à presença das espécies pioneiras, secundárias e tardias.

Palavras-Chave: Regeneração natural; Sucessão ecológica; Floresta tropical. 


\section{INTRODUCTION}

Tropical forests are habitats that house more than half of the world's biota and are among the most fragile ones (Wilson, 1997). The greater the biodiversity of a place or region, the greater the level of especialization of its components and the greater the interdependence of the components. In the face of disturbances, such as the opening of natural or anthropogenic clearings, regeneration of tropical forests can occur through seed production, soil seed bank, seedling bank, advanced regeneration, root regrowth or sprouts of damaged individuals and lateral growth of Treetops (Brokaw, 1985).

The soil seed bank is the set of non-germinated seeds present in the soil with the potential to replenish adult plants that are senesced by natural causes such as the life cycle or due to any disease, disturbance or consumption by animals, including man (Baker, 1989). The soil seed bank includes buried seeds, and seeds that are on the soil surface and in the litter (Garwood, 1989).

Several studies have demonstrated that the soil seed bank is an important mechanism in the regeneration of pioneer species in tropical regions (Guevara and Gómez-Pompa, 1979; Garwood, 1989; Araújo et al., 2001). These species play an important role as facilitators of the successional process. The existence of a viable seed bank in the soil is essential for secondary succession, facilitating the forest's recovery after disturbances and ensuring its sustainability. The time seeds stay viable in the soil is a function of their physiological properties, environmental conditions and the presence of predators and pathogens (Garwood, 1989).

According to Primack (1990), most trees in mature tropical forests produce fruits with large and heavy seeds, that is, with high water and nutrients content, which result in seedlings with extensive and often deep roots and large leaf area. If these seeds fall somewhere unfavorable to germination, they usually die because they do not go dormant. A second group of trees in mature tropical forests i produce smaller seeds, with less water and a hard shell. The species in this group have a number of types of germination, but many will remain dormant if conditions are not favorable. And a third group contains the pioneer species, which colonize clearings and areas where there are canopy gaps. The seeds of these trees are small, have low water content, and can remain dormant until germination conditions are favorable.

After any disturbance in the forest the first seed source for area recolonization are the dormant seeds in the seed bank. Knowledge about seed dormancy and the seed bank of a site provides predictions about which species are most likely to persist after a disturbance and is also important for forest management and conservation of genetic resources (Primack, 1990).

Baider et al. (2001) proposed that, in order to understand the real importance of the seed bank for tropical forest's regeneration, studies are essential to quantify how woody plants establishment is regulated by the seeds stored in the soil.

The present study is aimed at understanding the natural processes of forest maintenance and renewal and its regenerative potential in face of disturbances, as well as being able to account for environmental quality and the basis for future management and ecosystems recovery projects. The objective of this study is to verify if the density and floristic composition of the semideciduous forest fragment seed bank in Canchim Farm offers resilience potential. Therefore, the seed bank's germinability at the end of the dry and rainy seasons was analyzed and added to soil or litter, under greenhouse control.

\section{MATERIALAND METHODS}

The forest fragment under study is located in the municipality of São Carlos, in the central-eastern region of the State of São Paulo (22 01'22' 'S, 47 53'38' 'W), Brazil.

The region's climate is tropical at altitude, with dry seasons from April to September and humid season from October to March. According to Koepen's classification, the climate is Cwa, hot climate with dry winter, with the average temperature of the warmest month above $22^{\circ} \mathrm{C}$ and the average temperature of the coldest month below $18^{\circ} \mathrm{C}$ (Monteiro, 2000).

In 2003 the percentage of the municipality that still had vegetation was approximately $2.31 \%$ of Cerrado, $2.63 \%$ of Cerradão, $1.09 \%$ of Semideciduous and Riparian Seasonal Forest, which demonstrates the urgency to conserve the native vegetation remnants (Soares et al., 2003).

Revista Árvore. 2017;41(3):e410311

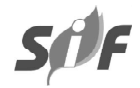


The Semideciduous Forest fragment is a legal reserve located in the Canchim Farm, São Carlos (SP) it is approximately 112 ha and its average altitude is 850 $\mathrm{m}$, with flat to slightly undulating topography that hasn't been exploited since 1934; the predominant soils are Latossolo Dark Red and Purple Earth; and the fragment lies within an agricultural and livestock matrix (Primavesi et al., 1999). The forest's canopy is between 7 and 25 $\mathrm{m}$ high, with no defined stratification; within the fragment there are several endangered plant species in the State of São Paulo (Silva and Soares, 2002) and numerous lianas (Hora et al., 2008).

In order to study the density and floristic composition of the Semideciduous Seasonal Forest's soil seed bank present at the Canchim Farm, samples were collected from the soil surface inside the fragment. Sampling was done in a fixed plot of $100 \mathrm{~m}$ X $100 \mathrm{~m}$ divided into subplots of $10 \mathrm{~m} \times 10 \mathrm{~m}$, in an area with good conservation status. The sampling points were chosen in the center of the subplots, distributed alternately assuring that field colletion and trampling would not alter the composition and proportion of the species. Sampling totaled 50 samples at the end of the dry season and 50 at the end of the rainy season. After the litter collection, soil was collected to a depth of $5 \mathrm{~cm}$, using a metal template of $0.25 \mathrm{~m} \times 0.25 \mathrm{~m}(0,0625 \mathrm{~m} 2)$.

The samples were stored in labeled plastic bags and transported to the greenhouse of the Botany Department of the Federal University of São Carlos (UFSCar). The litter and the soil were placed in polystyrene trays measuring $0.36 \times 0.25 \mathrm{~m}\left(0.09 \mathrm{~m}^{2}\right)$ previously drilled and coated with a layer of washed sand for drainage of excess water. The trays were arranged in benches under a shade covered vegetation filtering $20 \%$ of the sun's rays and irrigated whenever necessary to keep the soil moist. Two controls with washed sand were assembled in each experiment and randomly distributed to control contamination of external propagules. The germinated seedlings in the controls were considered contaminating species and were excluded from the analysis.

Soil seed bank analysis was performed through seedling counting. Monitoring of germination and seedling counts occurred weekly for six months. Specimens of most species (with the exception of shortcycle herbaceous species) were transplanted to sacks with soil from the site to facilitate growth and subsequent identification. Unidentified individuals while alive or lacking species confirmation were herborized. The identification of species was done by comparison in herbarium, consulting specialized literature and with the help of specialists.

Seedlings were counted and the individuals classified as tree, bush, herb or vine life form.

The Shannon-Wiener Diversity Index at base 10 $\left(\mathrm{H}^{\prime}\right)$ was calculated and the aggregation pattern of the species was verified, aiming to recognize random or aggregate patterns to the soil and / or litter with BiodiversityPro software. The correspondence analysis of the families with the litter and soil fractions was done with XLStat2009 software. The different morphospecies were considered for the various calculations.

\section{RESULTS}

An average of 307.8 and 144.0 seedlings $/ \mathrm{m}^{2}$ were found at the end of the rainy and dry seasons, respectively, belonging to 54 species, composed of 26 trees, 12 lianas, 12 shrubs, and 4 herbaceous plants.

The diversity Shannon-Wiener Diversity Index $\left(\mathrm{H}^{\prime}\right)$ for the species present $\mathrm{n}$ the seed bank in the rainy season was 0.951 , reaching $66.45 \%$ of the maximum possible environmental diversity represented by the Hmax of 1.431 . In the dry season the $\mathrm{H}$ 'was 1.265 and the Hmax was 1.724 , therefore $73.37 \%$ of the maximum diversity was reached (Zar, 1984).

The number of unidentified species was relatively high and they were classified as morphospecies (= 17); such high number was mainly due to seedling ephemeris (death after germination) and difficulty in identification at this stage of development.

In the rainy season, the families Euphorbiaceae, Moraceae, Asteraceae, Amaranthaceae and Caricaceae are more associated to litter, whereas Melastomataceae, Acanthaceae, Piperaceae, Ulmaceae, Rhamnaceae, Malvaceae and Cucurbitaceae are more associated with soil (Fig. 1).

In the dry season, the families associated with the litter were Urticaceae, Solanaceae, Euphorbiaceae, Asteraceae, Melastomataceae, and Palmae (Arecaceae) to the soil Ulmaceae, Rhamnaceae and Piperaceae and to both extracts the families Urticaceae and Fabaceae (Fig. 2). 


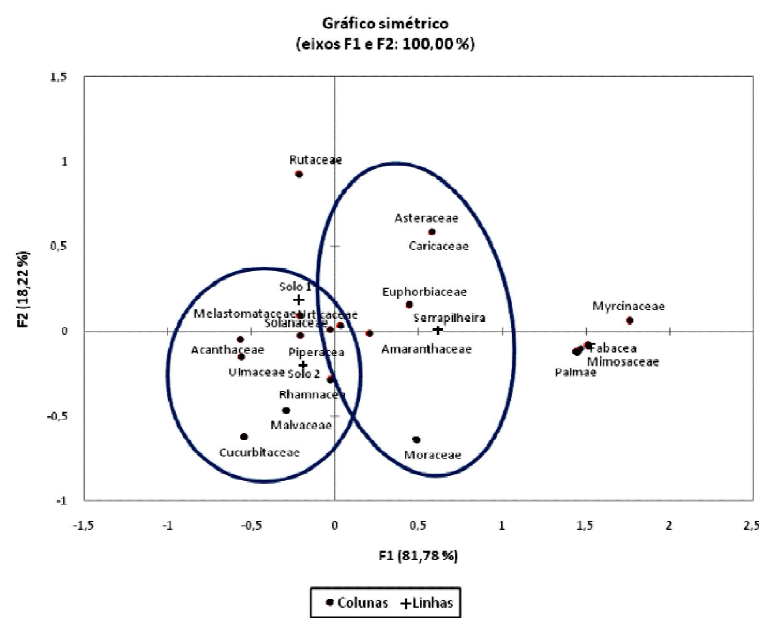

Figure 1 - Seed bank germination: families' correlation to soil and litter during the rainy season of a Semidecidual Forest fragment within Canchim Farm, São Carlos, SP, Brazil.

Figura 1 - Correspondência das famílias com fração solo e serapilheira, na estação chuvosa, no banco de sementes do fragmento de Floresta Estacional Semidecídua da Fazenda Canchim, São Carlos, SP, Br.

The species with the highest relative density were Cecropia glaziovi, Cecropia pachystachya and Piper aduncum, representing $24.4 \%, 11.5 \%$ and $10.8 \%$, respectively, of the seeds germinated in the rainy season.

In the dry season, Cecropia glaziovi, Cecropia pachystachya, Trema micrantha and Solanum mauritianum showed higher values of relative density (27.8\%, 19.1\%, 14.2\% and 14\%, respectively). Cecropia glaziovi was the dominant species from the soil seed bank of the study area with $25 \%$ of the individuals germinated from the two stations sampled.

\section{DISCUSSION}

Although methodological differences and different experimental design seedlings density values are below the average and the number of species of the average found by other authors. By comparison., : 756 seedlings $/ \mathrm{m}^{2}$ and 58 species in succession Amazonian forest Oriental (Araujo et al., 2001); 872 seedlings $/ \mathrm{m}^{2}$ and 85 species, mostly herbaceous in Atlantic Forest Montana (Baider et al., 1999); 508 individuals $/ \mathrm{m}^{2}$ and 38 species in Seasonal Forest in Viçosa-MG, Brazil (Braga et al., 2008); 736 seedlings $/ \mathrm{m}^{2}$ belonging to 66 species in the Seasonal Forest in Viçosa-MG, Brazil (Franco et

Revista Árvore. 2017;41(3):e410311

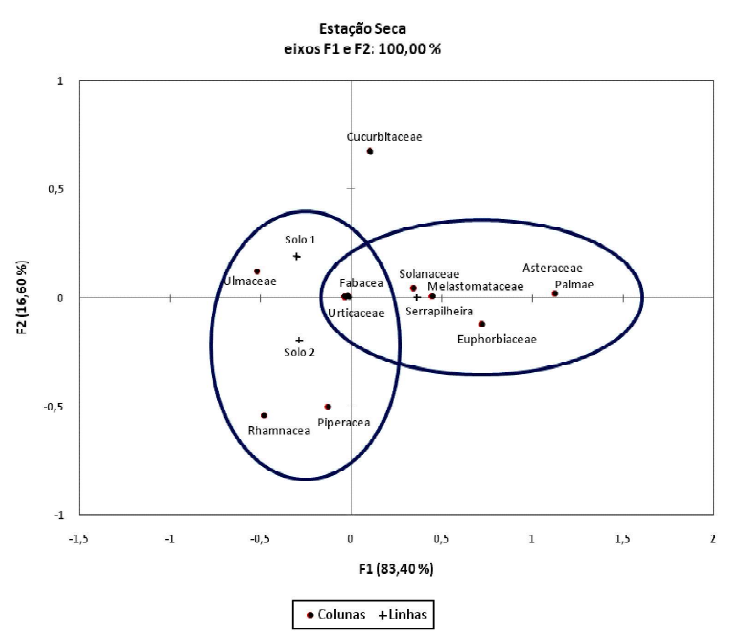

Figure 2 - Seed bank germination: families' correlation to soil and litter during the dry season of a Semidecidual Forest fragment within Canchim Farm, São Carlos, SP, Brazil.

Figura 2-Correspondência das famílias com fração solo e serapilheira, na estação seca, no banco de sementes do fragmento de Floresta Estacional Semidecídua da Fazenda Canchim, São Carlos, SP, Br.

al., 2012); $49.6 \pm 43.8$ seedlings $/ \mathrm{m}^{2}$ in the rainy season and $46.3 \pm 68.2$ seedlings $/ \mathrm{m}^{2}$ and dried at 54 Semideciduous Forest species in Campinas- SP, Brazil (Grombone-Guaratine and Rodrigues, 2002) and 588.6 and 800.3 seedlings $/ \mathrm{m}^{2}$ and 56 species and 66 in two sites with smaller and larger, respectively, disturbance seasonal Semideciduous forest in Botucatu-SP, Brazil (Martins and Engel, 2007). Low values are attributed to lower abundance of herbaceous species.

This work is in agreement with Grombone-Guaratine and Rodrigues (2002), who showed higher number of seeds that germinated in the rainy season, which is probably related to the most intense period of species fruiting, greater soil water availability and higher temperatures.

Although there was a low number of seeds in the forest studied, the in-kind richness was high with a large number of tree species. Of the 21 tree species identified in this study, 16 are cited by Silva and Soares (2002) as part of the arboreal component of this forest and four species belong to the Melastomataceae family that did not enter the computation of the phytosociological analysis of these authors probably due to methodological issues. Considering this information and the restrictions imposed by the methodological 
differences, the seedling sample can be considered representative of the canopy composition of species.

The values of viable seed density in seed banks should not be seen in isolation, as the trend of decreasing viable seed density with succession progression is cited by several authors such as Young et al. (1987) and Baider et al. (2001).

The families determined during the experiment were: Acanthaceae, Amaranthaceae, Asteraceae, Caricaceae, Cucurbitaceae, Euphorbiaceae, Fabaceae, Malvaceae, Melastomataceae, Moraceae, Palmae (Arecaceae), Piperaceae, Rhamnaceae, Solanaceae, Ulmaceae, and Urticaceae.

In the rainy season the families Euphorbiaceae, Moraceae, Asteraceae, Amaranthaceae, and Caricaceae were more associated to the litter, whereas Melastomataceae, Acanthaceae, Piperaceae, Ulmaceae, Rhamnaceae, Malvaceae, and Cucurbitaceae more associated to the soil. In the dry season, the families associated with litter were Urticaceae, Solanaceae, Euphorbiaceae, Asteraceae, Melastomataceae, and Palmae (Arecaceae); to the soil Ulmaceae, Rhamnaceae and Piperaceae; and to both extracts the families Urticaceae and Fabaceae.

Due to the two species of Cecropia, the family Urticaceae was present in the soil and litter fraction in the two sampled seasons, which can occur because of significant annual seed supply, dormancy and relatively small size ( 1 to $2 \mathrm{~mm}$ ) of the seeds. For the Melastomataceae family, it is probable that its occurrence is related to the temporal dynamics associated to its seeds, since in the dry season the seeds are related to the litter and in the rainy season to the soil. The Euphorbiaceae family showed correspondence with the litter in both seasons, although only Alchornea triplinervia germinated exclusively from it, which shows that the highest percentage of the seeds of the species present in the soil seed bank is associated with the litter layer. The Ulmaceae family, represented by Trema micrantha, presented higher germination coincident with the rainy season sampling and yet it was associated to the soil, probably due to its seed stock and longevity. The dominance of the family Urticaceae occurs, more prominently, in the rainy season with $46.9 \%$ of germinated seeds.

Also, according to Garwood (1989), forest seed banks are dominated by a species, often arboreal, determinant of regeneration, with values between
16 to $71 \%$, which corroborates with the results obtained; and the tree life form is predominant in forest ecosystems' seed banks with values ranging from 18 to $91 \%$ and an average value of $49 \%$. In the present sample, $75 \%$ of the individuals that germinated in the rainy season were arboreal and, in the dry season, the percentage increased to $78 \%$.

However, a statistically significant difference was observed in the plant habits' composition $(\mathrm{X} 2=91.5$, $\mathrm{GL}=3, \mathrm{p}<0.05)$ between the seasons; there was a significant increase in the relative abundance of lianas during the dry season, while trees, shrubs and grasses were more abundant during the rainy season.

According to Araujo et al. (2001), the distribution of life forms in the seed bank, in addition to other factors, is related to the pressure exerted by the environment on a micro regional scale, so areas that display greater forest ecosystem degradation may show a predominance of invasive herb and shrubs' species.

The observed variations in seed bank germination during the two sampled periods can be explained by the seasonality of the composition and seed density in the soil. This seasonality is a reflection of the species' characteristics regarding annual or seasonal reproduction modes and consequent deposition and storage of seeds in the soil (Dalling et al., 1997).

The pioneer tree species Cecropia glaziovi, Cecropia pachystachya, Croton floribundus, Solanum mauritianum, and Trema micrantha were found in the soil during both sampling periods.

According to data from Lorenzi (1998) and Carvalho (2003) species of the genus Cecropia present annual reproductive cycles, production of large seeds measuring between 1 to $2 \mathrm{~mm}$ and high natural longevity, being able to remain viable in the soil seed bank for up to 6 months. Seeds of these species were found in large numbers by different authors (Baider et al., 1999; Grombone-Guaratini and Rodrigues, 2002; Martins and Engel, 2007).

Trema micrantha also produces large amounts of seeds annually and fruits from January to May, their seeds are around $0.15 \mathrm{~cm}$ long and present endogenous dormancy, being able to maintain germinative power for up to two years in the soil (Lorenzi, 1998). According to Grombone-Guaratini et al. (2004) species of the genus Cecropia, Trema micrantha and Croton floribundus are typical of large clearings' regeneration.

Revista Árvore. 2017;41(3):e410311 
Table 1 - Species, habits, number of plants observed during the rainy season (EC) and dry season (ES) in the seed bank of a Semidecidual Forest within Canchim Farm, São Carlos, SP, Brazil.

Tabela 1 - Espécies, hábitos, número de indivíduos observados na estação chuvosa (EC) e na seca (ES) das espécies ocorrentes no banco de sementes do solo em Floresta Estacional Semidecídua na Fazenda Canchim, São Carlos, SP, Brasil.

\begin{tabular}{|c|c|c|c|c|}
\hline Family & Cientific Name & Habit & $\mathrm{EC}$ & ES \\
\hline Acanthaceae & Tricanthera sp. & Tree & 2 & 0 \\
\hline Amaranthaceae & Pfaffia paniculata (Mart.) Kuntze & Liana & 2 & 0 \\
\hline Arecaceae (Palmae) & Euterpe edulis Mart. & Tree & 7 & 1 \\
\hline Asteraceae & Mikania trinervis Hook. \& Arn. & Liana & 2 & 1 \\
\hline Caricaceae & Jaracatia spinosa (Aubl.) A.DC. & Tree & 2 & 0 \\
\hline Cucurbitaceae & Wilbrandia hibiscoides Manso & Liana & 4 & 2 \\
\hline Euphorbiaceae & Alchornea triplinervia (Spreng.) M. Arg. & Tree & 2 & 0 \\
\hline Euphorbiaceae & Croton floribundus Spreng. & Tree & 13 & 4 \\
\hline Euphorbiaceae & Dalechampia brasiliensis Vell. & Liana & 3 & 1 \\
\hline Euphorbiaceae & Dalechampia escandens Lam. & Liana & 5 & 15 \\
\hline Fabaceae (Mimosoidea) & Enterolobium contortisiliquum (Vell.) Morong & Tree & 1 & 1 \\
\hline Fabaceae (Mimosoideae) & Indeterminada & Tree & 2 & 0 \\
\hline Fabaceae (Mimosoideae) & Piptadenia gonoacantha Macbride & Tree & 15 & 0 \\
\hline Fabaceae (Papilionoidae) & Canavalia brasiliensis Mart.ex. Benth. & Liana & 2 & 3 \\
\hline Fabaceae (Papilionoidae) & Machaerium stipitatum (DC.) Vogel & Tree & 4 & 0 \\
\hline Malvaceae (Sterculiaceae) & Guazuma ulmifolia Lam. & Tree & 27 & 0 \\
\hline Melastomataceae & Leandra glazioviana Cogn. & Tree & 22 & 0 \\
\hline Melastomataceae & Leandra sp. & Tree & 23 & 0 \\
\hline Melastomataceae & Miconia discolor DC. & Tree & 54 & 2 \\
\hline Melastomataceae & Miconia pseudonervosa Cogn. & Tree & 31 & 3 \\
\hline Melastomataceae & Miconia sp. & Tree & 0 & 1 \\
\hline Moraceae & Ficus sp. & Tree & 55 & 0 \\
\hline Myrsinaceae & Rapanea umbellata (Mart.) Mez & Tree & 1 & 0 \\
\hline Myrtaceae & Eugenia florida D.C. & Tree & 9 & 0 \\
\hline Piperaceae & Piper aduncum Linn & Shrub & 104 & 8 \\
\hline Rhamnaceae & Gouania ulmifolia Hook. et Arn. & Liana & 22 & 15 \\
\hline Rutaceae & Conchocarpus pentandrus (A.St.-Hil.) Kallunki \& Pirani & Tree & 6 & 0 \\
\hline Solanaceae & Acnistus arborescens (L.) Schltdl. & Shrub & 11 & 2 \\
\hline Solanaceae & Solanum aculeatissimum Jacq. & Shrub & 10 & 4 \\
\hline Solanaceae & Solanum cf. argenteum Dunal. & Shrub & 10 & 2 \\
\hline Solanaceae & Solanum mauritianum Scop. & Tree & 43 & 63 \\
\hline Solanaceae & Solanum paniculatum L. & Shrub & 2 & 2 \\
\hline Solanaceae & Solanum sp. & Shrub & 2 & 0 \\
\hline Ulmaceae & Trema micrantha (L.) Blume & Tree & 22 & 64 \\
\hline Urticaceae & Cecropia glaziovi Snethlage & Tree & 235 & 125 \\
\hline Urticaceae & Cecropia pachystachya Trécul. & Tree & 111 & 86 \\
\hline \multirow[t]{5}{*}{ Urticaceae } & Urera baccifera (L.) Gaudich. Ex Wedd & Shrub & 1 & 0 \\
\hline & Tree Morfoespecies 3 & Tree & 16 & 0 \\
\hline & Shrub Morfoespecies 5 & Shrub & 7 & 9 \\
\hline & Herb Morfoespecies 4 & Herb & 55 & 11 \\
\hline & Liana Morfoespecies 5 & Liana & 13 & 22 \\
\hline
\end{tabular}

Species such as Guazuma ulmifolia, Piptadenia gonoacantha, Conchocarpus pentandrus, Machaerium stipitatum, Alchornea triplinervia, and Jaracatia spinosa germinated only in the rainy season sampling, which coincides with these species' fruit maturation period. These species are pioneers, with annual reproductive cycles; their seeds rapidly lose germination viability and measure between 0.3 and $1 \mathrm{~cm}$ (Lorenzi, 1998; Carvalho, 2003).

Euterpe edulis is a climax species, which fruits from April to August (Lorenzi, 1998). Its seeds present dormancy, but because they are recalcitrant, they lose their viability in up to 6 months (Carvalho, 2003).

Revista Árvore. 2017;41(3):e410311 
The various strategies of the fall, germination and establishment of seed bank species can occur concomitantly. A strategy is expected to predominate, although there is seasonal variation of predominance (Garwood, 1989). In the present study, we identified persistent seed bank strategies with Cecropia glaziovi, Cecropia pachystachya, Trema micrantha, and Enterolobium contortisiliquum; and transient seed bank strategies with the Guazuma ulmifolia, Piptadenia gonoacantha, Conchocarpus pentandrus, Machaerium stipitatum, Alchornea Triplinervia, Jaracatia spinosa, and Euterpe edulis. In May, after this study, lots of seedlings of Pachystroma longifolium (Nees) were found I.M.Johns in the same collection sites; though germination has not been verified in the latter study. It is likely that this species' seeds will fall and germinate rapidly or lose viability, a fact already highlighted by Lorenzi (1992). Similarly to this species, other species, may exhibit the same behavior and difficulty of being detected in a study of this nature unless soil collection is more frequent.

According to Garwood (1989), size and number of seeds produced are inversely proportional; so small seeds produced by early pioneer and secondary species are expected to dominate the soil seed bank. The study of Honda (2008) cites that the main factors related to the seed bank formation are life history and seed size, proposing that dormancy is not essential for the formation and persistence of the bank.

During the rainy season it was observed that the majority of the arboreal species corresponds to the litter. While the species of the genus Cecropia, Trema and those of the Melastomataceae family, pioneers recognized by seed bank formation potential, were concentrated in the soil fraction, perhaps the small size of the seeds facilitates transportation by rainwater.

In the dry season, Cecropia pachystachya was observed in the litter, possibly due to seed rain or dispersing agents. Euterpe edulis maintained the correspondence with the litter in both experiments, probably due to the relatively large size of their seeds.

Seed size is strongly related to the dispersion biology and the species' way of life, occupying a central position among the attributes that determine in which environmental opportunities a species is more competitive. A pattern, which occurs in the field, is the populations' tendency of having large seeds in

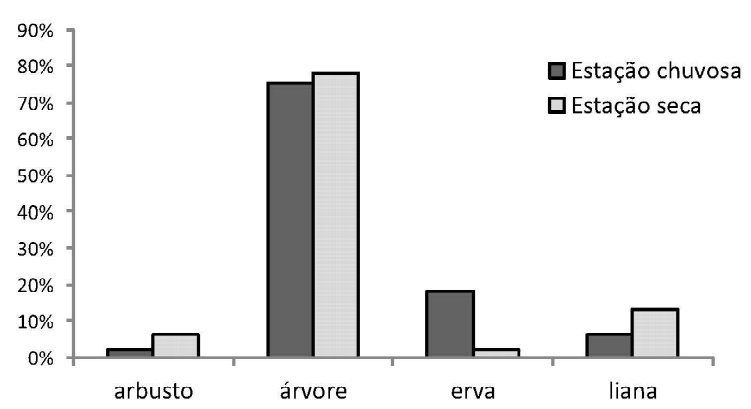

Figure 3 - Observed frequency by habit form of observed species in the seed bank during rainy and dry seasons of a Semidecidual Forest fragment within Canchim Farm, São Carlos, SP, Brazil

Figura 3-Frequências observadas na composição dos hábitos das espécies presentes no banco de sementes do solo na estação chuvosa e na estação seca do fragmento de Floresta Estacional Semidecídua da Fazenda Canchim, São Carlos, SP, Br.

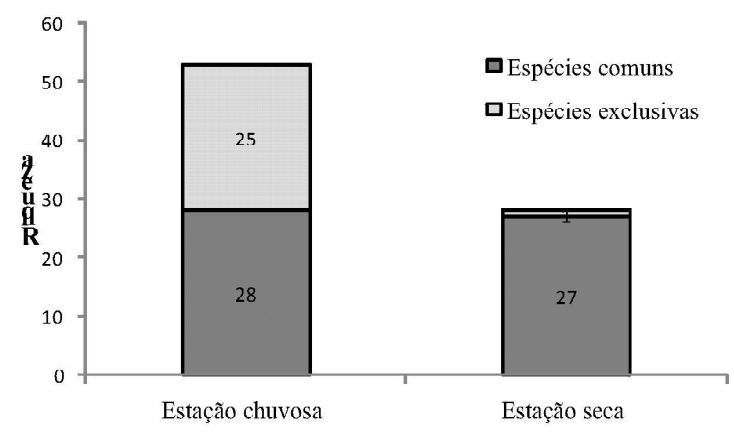

Figure 4-Observed richness of common and exclusive species during rainy and dry seasons in the seed bank of a Semidecidual Forest fragment within Canchim Farm, São Carlos, SP, Brazil

Figura 4-Riqueza de espécies comuns e exclusivas às estações chuvosa e seca observadas no banco de sementes do fragmento de Floresta Estacional Semidecídua da Fazenda Canchim, São Carlos, SP, Br.

species that have establishment of new individuals in the shade (Westoby et al., 2002).

The role of soil seed banks in tropical forests' regeneration is difficult to elucidate, since dormant seeds' regeneration from soil is rarely distinguished from regeneration originated from newly dispersed seeds in a given area (Brokaw, 1985; Garwood, 1989).

During sampling in the dry season an atypical pattern of rainfall was observed in the region. To characterize this fact a series of meteorological data 
obtained from the Canchim Meteorological Station regarding a short period of time was analized (https:/ /www.cppse. embrapa.br/080servicos/dadosmeteorologicos/tmp lista dados). It was observed that in the dry season of 2009 cumulative rainfall was highest between January 2005 and March 2010. This increase was gradual and, at the same time, accompanied by a decrease in rainfall accumulated during the rainy season. Thus, there was a tendency to decrease precipitation differences between the rainy and the dry seasons throughout the analyzed series; which led to the conclusion that there was not a markedly dry season during the seed bank's sampling period. This exceptionality of the meteorological data may have affected the soil' seeds bank data, but it is difficult to quantify.

The species observed in the dry season also occurred in the rainy season and 25 species occurred only in the rainy season.

The seasonal semideciduous forest presents changes in the aspect or behavior of its community according to the seasons of the year (IBGE, 1993; ACIESP, 1997). Thus, sequential monitoring studies of Fazenda Canchim's Semideciduous Seasonal Forest soil seed bank are necessary in order to understand their responses to the climatic dynamics.

\section{5-CONCLUSION}

The Semideciduous Forest remnant in Canchim Farm, São Carlos-SP presented a regeneration potential of its soil seed bank due to the density of germinated seeds and the number of species belonging to the various stages of succession, mainly pioneers.

The seed bank showed qualitative and quantitative differences between the dry and rainy seasons, and between the soil and litter samples: in the rainy season, higher species richness and number of seeds occurred, both in soil and litter; and there were larger seed species in the litter than in the dry season. For species pertaining to advanced stages of succession, which usually have short viability seeds, medium and long term studies are suggested, with samplings in the four seasons in order to better verify the patterns and dynamical processes of regeneration associated to the soil seed bank.

\section{6-ACKNOWLEDGEMENTS}

CAPES, for granting a doctoral scholarship to the first author.
To the Graduate Program in Ecology and Natural Resources of UFSCar, São Carlos.

To Embrapa - C. P.P.S.E, São Carlos, São Paulo for granting permission to perform this study.

\section{7-REFERENCES.}

ACIESP. Glossário de ecologia. $2^{a}$ ed. São Paulo: ACIESP, CNPq, FAPESP, Secretaria de Ciência e Tecnologia; 1997. 352p.

Araujo MA, Oliveira FA, Vieira IC, Barros PL, Lima CA. Densidade e composição florística do banco de sementes do solo de florestas sucessionais do Baixo Rio Guamá, Amazônia Oriental. Scientia Forestalis. 2001;59:115-30.

Baider C, Tabarelli M, Mantovani W. O banco de sementes de um trecho de Floresta Atlântica Montana (São Paulo, Brasil). Revista Brasileira de Biologia. 1999;59:319-28.

Baider C, Tabarelli M, Mantovani W. The soil seed bank during Atlantic Forest regeneration in southeast Brazil. Revista Brasileira de Biologia. 2001;61:35-44.

Baker HG. Some aspects of natural history of seed banks. In: Leck MA, Parker VT, Simpson RL editors. Ecology of soil seed banks. San Diego: Academic Press; 1989. p.9-21.

Braga AJT, Griffith JJ, Paiva HN, Meira-Neto JAA. Composição do banco de sementes de uma floresta semidecidual secundária considerando o seu potencial de uso para recuperação ambiental. Revista Árvore. 2008;32:1089-98.

Brokaw NVL. Gap-phase regeneration in a tropical forest. Ecology. 1985;66:682-7.

Carvalho PER. Espécies arbóreas brasileiras. Brasília, DF: Embrapa Informação Tecnológica; Colombo: Embrapa Florestas; 2003.

Dalling JW, Swaine MD, Garwood NC. Dispersal patterns and seed bank dynamics of pioneer trees in moist tropical forest. Ecology. 1998;79:564-78.

Franco BKS, Martins SV, Faria PCL, Ribeiro GA. Densidade e composição florística do banco de sementes de um trecho de Floresta Estacional Semidecidual no campus da Universidade Federal

Revista Árvore. 2017;41(3):e410311 
de Viçosa, Viçosa, MG. Revista Árvore. 2012;36:423-32.

Garwood NC. Tropical soil seed banks: a review. In: Leck MA, Parker VT, Simpson RL editors. Ecology of soil seed banks. San Diego: Academic Press; 1989. p.149-209.

Grombone-Guaratini MT, Rodrigues RR. Seed bank and seed rain in a seasonal semi-deciduous forest in south-eastern Brazil. Journal of Tropical Ecology. 2002;18:759-74.

Grombone-Guaratini MT, Leitão Filho HF, Kageyama PY. The seed bank of a gallery forest in Southeasthern Brazil. Brazilian Archives of Biology and Technology. 2004;47:793-7.

Guevara SS, Gómez-Pompa A. Seeds from surface soils in a tropical region of Veracruz, Mexico. Journal of the Arnold Arboretum. 1972;53:312-35.

Honda Y. Ecological correlations between the persistence of the soil seed bank and several plant traits, including seed dormancy. Plant Ecology. 2008;196:301-9.

Hora RC, Primavesi O, Soares JJ. Contribuição das folhas de lianas na produção de serapilheira em um fragmento de floresta estacional semidecidual em São Carlos, SP. Revista Brasileira de Botânica. 2008;31:277-85.

Instituto Brasileiro de Geografia e Estatística IBGE. Classificação da vegetação brasileira, adaptada a um sistema universal. Rio de Janeiro: 1993. 123p.

Lorenzi H. Árvores Brasileiras: manual de identificação e cultivo de plantas arbóreas nativas do Brasil. $2^{\mathrm{a}}$.ed. Nova Odessa: Plantarum; 1992. v.1

Lorenzi H. Árvores Brasileiras: manual de identificação e cultivo de plantas arbóreas nativas do Brasil. $2^{\text {a }}$.ed. Nova Odessa: Plantarum; 1998. v.2
Martins AM, Engel VL. Soil seed banks in tropical forest fragments with different disturbance histories in southeastern Brazil. Ecological Engineering. 2007;31:165-74.

Monteiro CAF. A dinâmica climática e as chuvas no estado de São Paulo. Versão 1.0. [CD-ROM] Rio Claro: UNESP; 2000.

Primack RB. Seed physiology, seed germination and seedling ecology - commentary. In: Simpson RL, Leck MA, Parker VT. Ecology of soil seed banks. San Diego: Academic Press; 1990.

Primavesi O, Primavesi ACPA, Pedroso AF, Camargo AC, Rassini JB, Rocha Filho J. et al. Microbacia Hidrográfica do Ribeirão Canchim: Um modelo real de laboratório ambiental. São Carlos: Embrapa Pecuária Sudeste; 1999. (Boletim de pesquisa, 5).

Silva LA, Soares JJ. Levantamento fitossociológico em um fragmento de floresta estacional semidecídua, no município de São Carlos, SP. Acta Botânica Brasílica. 2002;16:205-16.

Soares JJ, Silva DW, Lima MIS. Current situation and projection of the probable original vegetation of the São Carlos district of São Paulo, Brazil. Brazilian Journal of Biology. 2003;63:527-36.

Westoby M, Falster DS, Moles AT, Vesk PA. Wright IJ. Plant ecological strategies: Some leading dimensions of variation between species. Annual Review of Ecology and Systematics. 2002;33:125-59

Wilson EO. Biodiversidade. Rio de Janeiro: Nova Fronteira; 1997.657p.

Young KR, Ewel JJ, Brown BJ. Seed dynamics during forest succession in Costa Rica. Vegetatio.1987;71:157-73.

Zar JH. Biostatistical analysis. $2^{\text {nd }}$.ed. Englewood Cliffs: Prentice-Hall, 1984. 